\title{
Phosphorus acquisition by wheat from organic and inorganic sources labelled with ${ }^{32} \mathrm{P}$
}

\section{and ${ }^{33} \mathrm{P}$ radioisotopes}

\author{
Franklin M. Scrase ${ }^{1}$, Fergus L. Sinclair ${ }^{1}$, John F. Farrar ${ }^{1 \oplus}$, Paulo Sergio Pavinato ${ }^{2 *} \oplus$, Davey L. Jones ${ }^{3 \oplus}$
}

\author{
${ }^{1}$ Bangor University/Environment Center Wales, LL57 2UW - \\ Bangor, Gwynedd - United Kingdom. \\ 2Universidade de São Paulo/ESALQ - Depto. de Ciência do \\ Solo, Av. Pádua Dias, 11 - 13418-900 - Piracicaba, SP - \\ Brasil. \\ 3University of Western Australia/School of Agriculture and \\ Environment, 35 Stirling Highway - 6009 - Perth, WA - \\ Australia. \\ *Corresponding author < pavinato@usp.br>
}

Edited by: Paulo Cesar Sentelhas

Received July 24, 2018

Accepted November 25, 2018

\begin{abstract}
Investment in soil phosphorus $(P)$ capital in the tropics is often constrained by poor availability of mineral fertiliser to small-scale farmers. Consequently, new sustainable agricultural cropping strategies are required to maintain fertility and maximise crop yields. The co-application of Tithonia diversifolia (Tithonia) green manure and mineral fertiliser $\left(\mathrm{KH}_{2} \mathrm{PO}_{4}\right)$ together (integrated nutrient management) in comparison to the addition of one or the other alone has been hypothesized to promote crop P uptake. The aim of this study was to critically evaluate the benefits of integrated nutrient management practices in laboratory experiments. Wheat was grown as a test crop in microcosms to which either ${ }^{32} \mathrm{P}$-labelled mineral fertiliser or ${ }^{33} \mathrm{P}$-labelled Tithonia was added either singly or in combination. Exclusion meshes were used to determine the role of arbuscular mycorrhizal (AM) fungi in $P$ uptake from the different $P$ sources. The rate of uptake of both ${ }^{32} \mathrm{P}$ and ${ }^{33} \mathrm{P}$ by mycorrhizas was similar, and the rate of mycorrhizal $\mathrm{P}$ capture was comparable to that of roots. Generally, there was little difference in wheat $P$ acquisition under integrated nutrient management treatments in comparison to $\mathrm{P}$ acquisition from ${ }^{32} \mathrm{P}$-mineral fertiliser or the addition of ${ }^{33} \mathrm{P}$-Tithonia alone. Overall, Tithonia residues were not very effective in supplying $\mathrm{P}$ to wheat over a short time evaluation period, suggesting that mineral fertilisers will still be required to satisfy crop demand.
\end{abstract}

Keywords: Tithonia diversifolia, ${ }^{32} \mathrm{P}-$ labelled mineral fertiliser, ${ }^{33} \mathrm{P}-$ labelled tithonia, green manure, sustainable agriculture

\section{Introduction}

Low-input agricultural systems typically result in low productivity and farm poverty, largely due to soil fertility constraints but also including limited access to land, low financial capital, high vulnerability and low market participation (Kuivanen et al., 2016; Jama et al., 2000). Phosphorus $(\mathrm{P})$ is among the most intractable constraints on fertility, particularly in acid soils in the tropics which possess a high $\mathrm{P}$ fixation capacity (Withers et al., 2018; Rodrigues et al., 2016; Roy et al., 2016). Where crop plants are grown under limited $\mathrm{P}$, low yields are associated with slow crop canopy closure, resulting in leaching of mobile mineral nutrients and loss of topsoil by erosion (Fairhurst et al., 1999).

Large amounts of $\mathrm{P}$ fertiliser in tropical soils are needed to supply $\mathrm{P}$ demand (Roy et al., 2016), and the combined input of fertilisers, good soil/crop management and green manure plants can render degraded soils highly productive (García-González et al., 2018). Use of $\mathrm{P}$ fertilisers by resource-poor farmers in some parts of the world is minimal. Consequently, sustainable management of these soils requires organic additions to replenish soil organic matter $(\mathrm{OM})$ and recycle more nutrients. It has long been recognised that the addition of $\mathrm{OM}$ to soils can increase plant $\mathrm{P}$ availability (Kolawole et al., 2013). Organic anions added directly via OM or formed during its mineralisation may become adsorbed to the soil sorption sites thereby reducing the $\mathrm{P}$ sorptivity of the soil (Iyamuremye et al., 1996), and increasing the availability of $\mathrm{P}$ for crops.
In recognition of the benefits of organic residue additions, green manure species like Tithonia, which possesses a high $\mathrm{P}$ content ( 3 to $4 \mathrm{~g} \mathrm{~kg}^{-1}$ dry weight), has been identified as a species capable of recycling and supplying a substantial amount of nutrients to the subsequent cash crop (Olabode et al., 2007; Ganunga et al., 2005; Nziguheba et al., 1998, 2002; Jama et al., 2000). Field studies have indicated that combined applications of Tithonia and small amounts of mineral P can increase maize yields in comparison to traditional fertiliser use (Nziguheba et al., 1998, 2002); however, the mechanistic basis of these interactions remains unknown. The present study was undertaken to evaluate if the combination of organic $\left({ }^{33} \mathrm{P}\right.$ in Tithonia tissue) and mineral $\mathrm{P}\left({ }^{32} \mathrm{P}\right.$ fertiliser) sources are more effective in promoting wheat growth than a mineral source alone, and to determine the dominant processes influencing $\mathrm{P}$ uptake by wheat from combined organic and mineral $\mathrm{P}$ soil treatments.

\section{Materials and Methods}

\section{Preparation of ${ }^{33} \mathrm{P}$-labelled Tithonia}

Tithonia diversifolia (Hemsl.) A Gray seeds of Kenyan origin were imbibed for $12 \mathrm{~h}$ in aerated distilled water and then placed onto moist filter paper at $20^{\circ} \mathrm{C}$ to germinate. After 5 days, individual seedlings $(3$ to 5 $\mathrm{cm}$ tall) were transferred to $3.5 \mathrm{~L}$ containers containing an aerated $\left(1 \mathrm{~L} \mathrm{~min}^{-1}\right) 80 \%$ strength Long Ashton nutrient solution (Hewitt, 1966). The nutrient solution was amended with $\mathrm{NaH}_{2}{ }^{33} \mathrm{PO}_{4}$ (specific activity $300 \mathrm{kBq} \mathrm{mg}^{-1}$ P; Amersham Pharmacia Biotech Ltd., Little Chalfont, 
Bucks.) and the plants placed in a climate-controlled growth room with $22 / 18{ }^{\circ} \mathrm{C}$ day/night temperatures, 16 -h photoperiod and a light intensity of $500 \mu \mathrm{mol} \mathrm{m} \mathrm{m}^{-2}$ $\mathrm{s}^{-1}$. After 21 days, all the ${ }^{33} \mathrm{P}$ in the root-bathing solution had been removed by the plants. At harvest, the shoots had a $170 \mathrm{~g} \mathrm{~kg}^{-1}$ dry weight, with $\mathrm{P}$ and $\mathrm{N}$ content of 2.3 and $25 \mathrm{~g} \mathrm{~kg}^{-1}$, respectively.

\section{Soil characterization}

Soil was obtained from the Ap horizon $(0-20 \mathrm{~cm})$ of a Eutric Fluvisol (IUSS, 2015) located in Bharatpur, Nepal $\left(27^{\circ} 36^{\prime} \mathrm{N}, 84^{\circ} 22^{\prime} \mathrm{E}\right.$; altitude $187 \mathrm{~m}$; rainfall of $2500 \mathrm{~mm} \mathrm{yr}^{-1}$ ) in which maize (Zea mays L.) and wetland rice (Oryza sativa L.) had been previously grown in rotation. The soil is a poorly structured sandy loam with a $\mathrm{pH}_{\left(\mathrm{H}_{2} \mathrm{O}\right)}$ of 5.48 , total organic $\mathrm{C}$ content of $0.51 \%$, total $\mathrm{N}$ content of $0.03 \%, \mathrm{C}: \mathrm{N}$ ratio of 17 and electrical conductivity $\left(\mathrm{H}_{2} \mathrm{O} ; 1: 1 \mathrm{v} / \mathrm{v}\right)$ of $0.13 \mathrm{mS} \mathrm{cm}^{-1}$. The exchangeable cation content determined by $1 \mathrm{M}$ ammonium chloride $\left(\mathrm{mmol}_{\mathrm{c}} \mathrm{kg}^{-1}\right)$ was as follows: $\mathrm{K}, 24 ; \mathrm{Na}, 4 ; \mathrm{Ca}, 84 ; \mathrm{Mg}, 60$. The soil presented a resin extractable $\mathrm{P}$ of $3.7 \mathrm{mg} \mathrm{kg}^{-1}$, a $0.5 \mathrm{M} \mathrm{NaHCO}_{3}(\mathrm{Olsen} \mathrm{P})$ extractable $\mathrm{P}$ content of $18 \mathrm{mg}$ $\mathrm{kg}^{-1}$ and a total $\mathrm{P}$ content of $202 \mathrm{mg} \mathrm{kg}^{-1}$. After collection, the soil was sieved through a $2 \mathrm{~mm}$ mesh and stored at field moisture levels at $15{ }^{\circ} \mathrm{C}$ until the experiment had been established.

\section{Rhizotron design}

The rhizotrons employed in this experiment were similar to those described by Marschner (1995) and consisted of a $150 \times 150 \times 20 \mathrm{~mm}$ box made from clear plexiglass. On each side of the box a 5-cm-diameter hole was cut to allow attachment of a soil-filled sub-compartment containing ${ }^{33} \mathrm{P}$ or ${ }^{32} \mathrm{P}$ (Figure 1).

The circular sub-compartments were composed of a 1-cm-long section of nylon pipe that could be isolated from the main compartment by means of a nylon mesh. Two mesh sizes were used to selectively prevent roots from entering the sub-compartment: (A) $2000 \mu \mathrm{m}$ mesh, allowing the passage of both mycorrhizal hyphae and roots and (B) $45 \mu \mathrm{m}$ mesh, allowing the passage of mycorrhizal hyphae but not the roots. Washed quartz sand (50 g) was placed at the base of the main compartment of each rhizotron and a $10 \mathrm{~mm}$ plastic pipe was placed vertically on one side so that the soil could be watered from the base.

Soil (500 g) was then packed into the main compartment of each rhizotron to a bulk density of $1.3 \mathrm{~g}$ $\mathrm{cm}^{-3}$. The sub-compartment soil was amended with either ${ }^{33} \mathrm{P}$-labelled Tithonia residues (organic $\mathrm{P}$; Po) or ${ }^{32} \mathrm{P}$-labelled $\mathrm{KH}_{2} \mathrm{PO}_{4}$ (inorganic $\mathrm{P} ; \mathrm{Pi}$ ) as outlined in Table 1. A total of $3 \mathrm{mg} \mathrm{P}$ was added to each set of rhizotron sub-compartments as either Tithonia ${ }^{33} \mathrm{Po},{ }^{32} \mathrm{Pi}$ or as a combination of the two (specific activity: $80 \mathrm{kBq} \mathrm{mg}^{-1} \mathrm{P}$ ). The relative half-life of ${ }^{32} \mathrm{P}$ is 14.3 days while for ${ }^{33} \mathrm{P}$ it is 25.2 days (Brown, 1971). The rate of $\mathrm{P}$ application was chosen so as to represent a $10 \mathrm{~kg} \mathrm{P}$ per ha $\mathrm{h}^{-1}$ application on a surface area on a rhizotron basis. This fertiliser addition rate was chosen to reflect typical $\mathrm{P}$ addition rates in the region where the soil was collected. The sub-compartment $\mathrm{P}$ application constituted a $\mathrm{P}$ 'hotspot', comparable to that which can be created as the result of a fertiliser application.

In the Tithonia ${ }^{33}$ Po-only treatments, $3.85 \mathrm{~g}$ fresh weight of ${ }^{33} \mathrm{P}$ labelled Tithonia shoot was well mixed with $25 \mathrm{~g}$ of soil (half volume of the ring to be connected to the rhizotron) and added to each sub-compartment providing a total of $3 \mathrm{mg}{ }^{33} \mathrm{P}$ per rhizotron, equivalent to $10 \mathrm{~kg} \mathrm{P} \mathrm{ha}^{-1}$ considering the $0-20 \mathrm{~cm}$ surface layer. The amount of organic material added was equivalent to ca. $12 \mathrm{t} \mathrm{ha}^{-1}$ on a fresh weight basis. These amounts are in line with green manure produc-

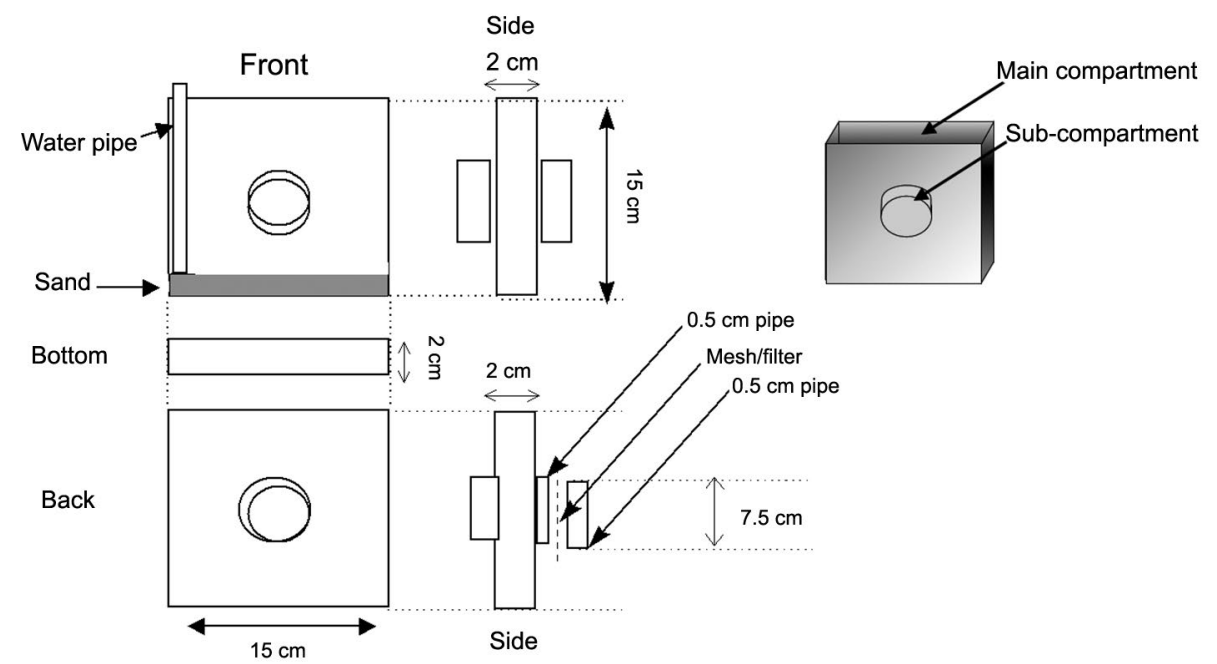

Figure 1 - Schematic design of rhizotrons used in the experiment, displaying a double-sided sub-compartment system where the labelled $\mathrm{P}$ sources were applied. 
Table 1 - Summary of treatments applied to wheat cultivated in the rhizotrons. ${ }^{33} \mathrm{P}$-labelled organic $\mathrm{P}(\mathrm{Po})$ and ${ }^{32} \mathrm{P}$-labelled mineral $\mathrm{P}$ (Pi) were added to the two sub-compartments in the rhizotron.

\begin{tabular}{|c|c|c|c|c|}
\hline \multirow{2}{*}{ Added $\mathrm{P}$ source } & \multirow{2}{*}{ Root access to sub-compartment } & \multicolumn{2}{|c|}{ Sub-compartment content } & \multirow{2}{*}{ Abbreviation } \\
\hline & & A & B & \\
\hline Organic & - & $P_{0}$ & $P_{0}$ & $P_{0}-R$ \\
\hline Organic & + & $P_{0}$ & $P_{0}$ & $P_{0}+R$ \\
\hline Mineral & - & $P_{i}^{0}$ & $P_{i}$ & $P_{i}-R$ \\
\hline Mineral & + & $P_{i}$ & $P_{i}$ & $P_{i}+R$ \\
\hline Organic plus mineral & - & $P_{i}$ & $P_{0}$ & $P_{\delta} / P_{i}-R$ \\
\hline Organic plus mineral & + & $P_{i}$ & $P_{0}$ & $P_{\delta} / P_{i}+R$ \\
\hline Organic plus mineral & - & $P_{i}+P_{0}$ & $P_{i}+P_{0}$ & $P_{0}+P_{i}-R$ \\
\hline Organic plus mineral & + & $P_{i}+P_{0}$ & $P_{i}+P_{0}$ & $P_{0}+P_{i}+R$ \\
\hline None & + & None & None & Control \\
\hline
\end{tabular}

tion rates (Sakai et al., 2011; Souza et al., 2017). In the ${ }^{32} \mathrm{Pi}$-only treatments, $150 \mu \mathrm{L}$ of $10 \mathrm{mg}^{32} \mathrm{P} \mathrm{mL}^{-1}$ was well mixed with $25 \mathrm{~g}$ of soil and added to each sub-compartment to again provide a total of $3 \mathrm{mg}{ }^{32} \mathrm{P}$ per rhizotron. In treatments where organic and mineral $P$ were added separately to sub-compartments, the same, previously mentioned amount of Tithonia shoot and $\mathrm{KH}_{2} \mathrm{PO}_{4}$ were well mixed with $25 \mathrm{~g}$ of soil each and attached to either side of the rhizotron. In treatments where organic and mineral $\mathrm{P}$ were added as a mixture, the $\mathrm{P}_{\mathrm{o}}(1.925$ $\mathrm{g}$ of Tithonia fresh weight) and $\mathrm{P}_{\mathrm{i}}(75 \mu \mathrm{L}$ of $10 \mathrm{mg} \mathrm{P}$ $\mathrm{mL}^{-1}$ ) were mixed evenly in $25 \mathrm{~g}$ of soil, placed in the sub-compartments and attached to either side of the rhizotron. The ${ }^{33 / 32} \mathrm{P}$-labelled soil was packed into the sub-compartment to a depth of approximately $0.5 \mathrm{~cm}$, providing a bulk density of about $1.3 \mathrm{~g} \mathrm{~cm}^{-3}$.

A further $0.5 \mathrm{~cm}$ layer (buffer strip) of soil containing no added $\mathrm{P}$ was placed on top of the radiolabelled soil layer, the nylon mesh placed over the buffer strip end, and a sub-compartment attached to each side of the rhizotron. To minimise the broader nutritional effects of adding green manure to the soil (Tithonia residues), mineral nutrients were added to the main compartment of all the rhizotrons as follows $\left(\mathrm{mg} \mathrm{kg}^{-1}\right): \mathrm{N}, 40 ; \mathrm{K}, 60$; $\mathrm{Ca}, 80 ; \mathrm{Mg}, 24 ; \mathrm{S}, 24 ; \mathrm{Mo}, 1.2 ; \mathrm{Cu}, 2.4 ; \mathrm{Zn}, 2.4 ; \mathrm{B}, 2.4$.

\section{Plant growth}

Seeds of wheat (Triticum aestivum cv. Abbott) were soaked in distilled water for $12 \mathrm{~h}$ and then transferred to moist filter paper to germinate. After $2 \mathrm{~d}$, three germinated seedlings were transplanted with equal spacing into each rhizotron. The rhizotrons were maintained in a climate-controlled growth room with $22 / 18{ }^{\circ} \mathrm{C}$ day/night temperatures, $16-\mathrm{h}$ photoperiod and a light intensity of $500 \mu \mathrm{mol} \mathrm{m} \mathrm{m}^{-2} \mathrm{~s}^{-1}$. The moisture content of the rhizotrons was maintained at approximately $20 \%$ volumetric water content by the daily addition of distilled water. After three and five weeks, the plants were fertilised with 29 mg of $\mathrm{NH}_{4} \mathrm{NO}_{3}$ Each treatment was replicated four times and the individual rhizotrons were randomly distributed within the growth cabinet (using random numbers to allocate the initial position) and rotated within the cabinet daily to reduce positional effects.

\section{Wheat harvesting and radioisotope $\mathbf{P}$ absorption}

Wheat was harvested after six weeks growth in the rhizotrons. The wheat shoots in each rhizotron were harvested by cutting plants at the soil surface, while the root part was obtained after water washing soil/roots in a mesh sieve $(2 \mathrm{~mm})$. Shoots and roots were oven-dried at $60{ }^{\circ} \mathrm{C}(72 \mathrm{~h})$ to determine dry matter weight (DW) and subsequently ground using a stainless-steel ball mill. A representative $40 \mathrm{mg}$ sample of the shoot was ashed $\left(500{ }^{\circ} \mathrm{C}, 24 \mathrm{~h}\right)$ and the residue dissolved in $1 \mathrm{M} \mathrm{HCl}$ (Baker and Greweling, 1967). The ${ }^{33 / 32} \mathrm{P}$ content of the $\mathrm{HCl}$ solutions was then determined by liquid scintillation counting using an $\mathrm{HCl}$-compatible scintillation fluid and liquid scintillation counter with automated quench correction. It was not possible to estimate the ${ }^{33 / 32} \mathrm{P}$ content in the root fraction because of soil contamination during the washing process, which subsequently interfered with the scintillation counter readings. The ${ }^{31} \mathrm{P}$ content of shoot material was determined in an aliquot from the $1 \mathrm{M} \mathrm{HCl}$ solutions using Murphy and Riley's (1962) colorimetric-based molybdate blue procedure.

\section{Statistical analysis}

All isotopic measurements were corrected for isotopic decay prior to carrying out any statistical analysis. The experiment had a two level factorial design, with four treatments (Po only, Pi only, Po and Pi in separated compartments, and $\mathrm{Po}+\mathrm{Pi}$ together in both compartments) for each interaction (with roots and without roots) and a control. The significance of interactions between $\mathrm{P}$ source/location and access to the $\mathrm{P}$ source were determined by a two-way ANOVA analysis using PROC GLM in SAS (Statistical Analysis System, version 9.3). Tukey's test was used for multiple comparisons between the sample means where the ANOVA F statistic was significant; $p<0.05$ was used as the cut-off for statistical significance. Linear regression analysis was used to correlate ${ }^{31} \mathrm{P}$ tissue ratio (shoot:root) and root:shoot ratio.

\section{Results}

The rhizotron design incorporating the exclusion meshes appeared to operate successfully in our experi- 
ment. The $2000 \mu \mathrm{m}$ mesh permitted free passage of roots into the sub-compartment while the $45 \mu \mathrm{m}$ mesh prevented root growth into the sub-compartment. In the ' $45 \mu \mathrm{m}$ mesh' treatments, a root mat similar to the one observed in the '2000 $\mu \mathrm{m}$ mesh' sub-compartment was found to form on the outer mesh surface.

Both shoot and root DW were affected by the supplement of both $\mathrm{Pi}$ and Po sources in sub-compartments (Figure 2). Treatments with root access to 'fertiliser ${ }^{32} \mathrm{Pi}^{\prime}$ or 'Tithonia and Pi together' had a shoot DW significantly greater than the 'Tithonia with roots excluded' treatment $(p<0.05)$. The fact there were no differences observed between the control and other treatments indicates no restriction of soil $\mathrm{P}$ availability in this treatment (control). The mean root DW for each treatment had a similar pattern to the mean shoot DW, although the differences between the means were not significant $(p<0.05)$.

Root:shoot ratios are shown in Figure 3. Despite access to additional $\mathrm{P}$, only when all the added $\mathrm{P}$ fertiliser was supplied in the mineral form was there an indication of reduced allocation of resources to the roots, with a root:shoot ratio of $\sim 0.60$, indicating in this case that $\mathrm{P}$ availability was probably not the major constraint on growth. For all the other treatments the root:shoot ratio was between $0.75-0.85$, with high root development, possibly as a consequence of plant restricted access to available $P$.

The proportion of the root growing in the available $\mathrm{P}$ hotspot provides an indication of plant responses to $\mathrm{P}$ fertiliser regimes (Figure 4). Relative to the control,

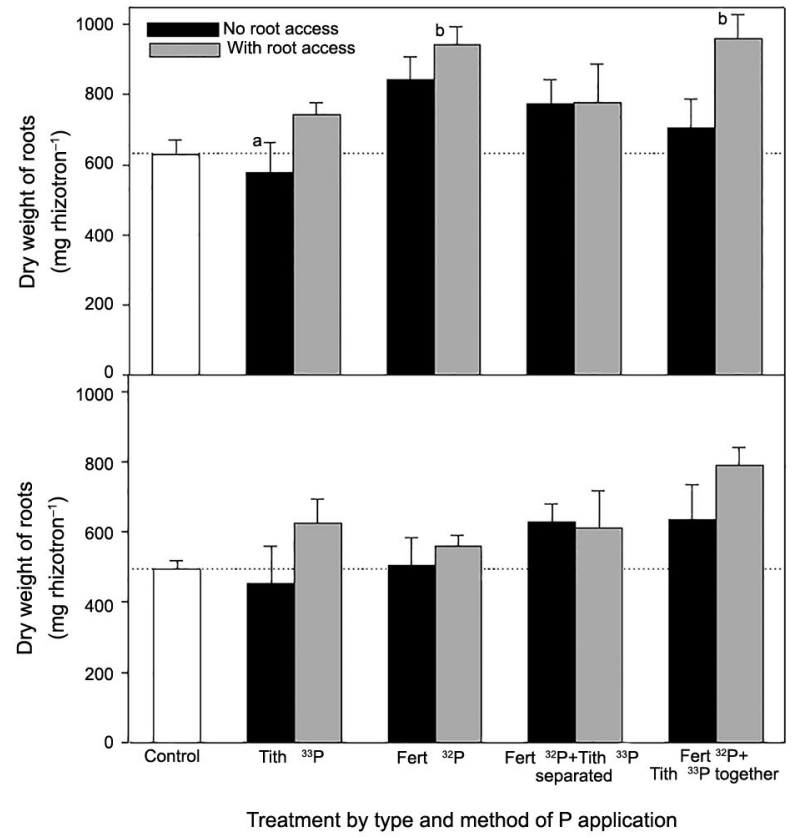

Figure 2 - Dry weight of wheat shoots and roots under organic and mineral $P$ sources, with significant differences between treatments indicated by letters, $(p<0.05)$. Bars represent standard errors of the means for each treatment $(n=4)$. proportionately, more of the root systems of the $\mathrm{Pi}$ and 'Tithonia-Po and Pi combined' treatments were detected in the $\mathrm{P}$ hotspot. When Tithonia and $\mathrm{Pi}$ additions were in separate compartments, root development in the subcompartment did not exceed those of the controls.

Total shoot $\mathrm{P}$ and total shoot radiolabelled ${ }^{32} \mathrm{P}$ or ${ }^{33} \mathrm{P}$ taken up by wheat in each rhizotron is shown in Figures 5 and 6, respectively. The amount of 'native' ${ }^{31} \mathrm{P}$ accumulated in the shoots was highly variable, represented here by the difference between total $\mathrm{P}$ (Figure 5) and radiolabelled $P$ (Figure 6). The Tithonia-only treatments and the combined 'Tithonia and ${ }^{32} \mathrm{Pi}$ with root access' treatments had a total $\mathrm{P}$ uptake to shoots similar to the control, despite access to the radiola-

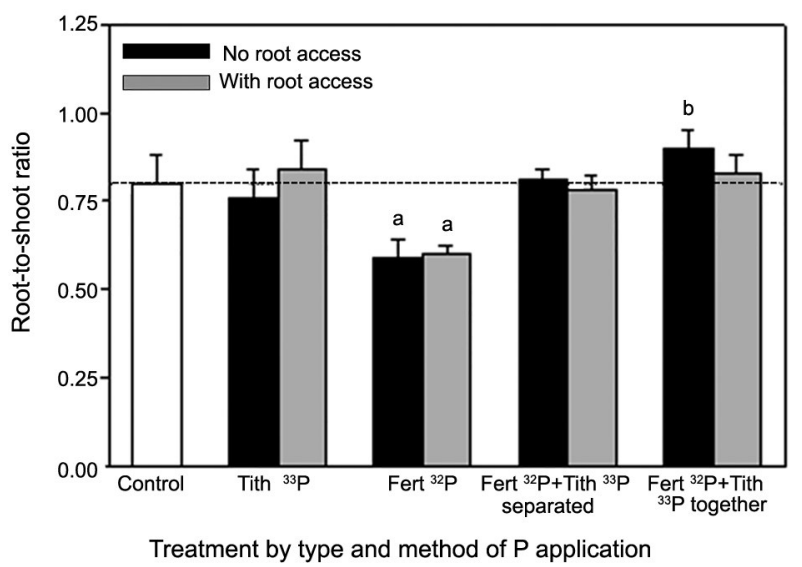

Figure 3 - Root:shoot ratio of wheat under organic and mineral $P$ sources, with significant differences from the control indicated by letters, $(p<0.05)$. Bars are for the standard error of the mean for each treatment $(n=4)$.

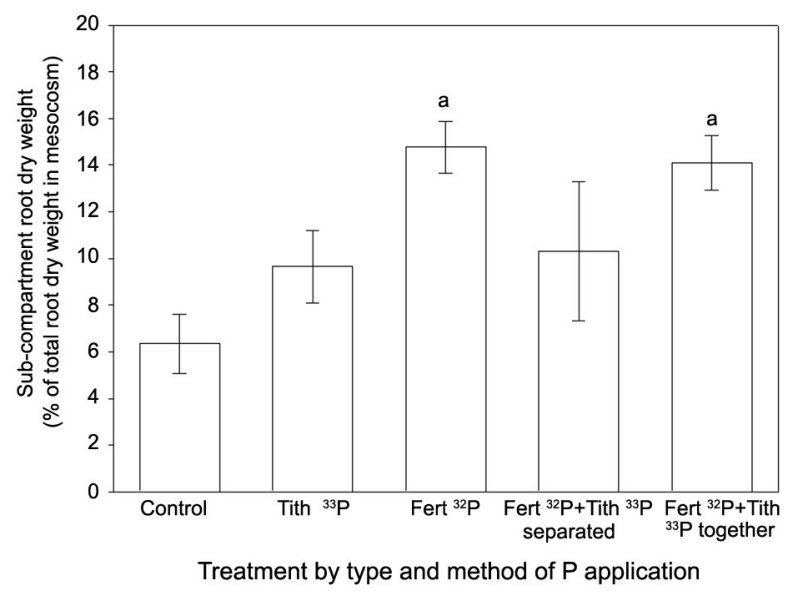

Figure 4 - The proportion of total root dry weight of treatments with access to the sub-compartments with labelled P. Values are expressed as a percentage of the total root DW. Significant differences from the control are indicated by letters $(p<0.05)$. Bars are for the standard error of the mean for each treatment $(n=4)$. 


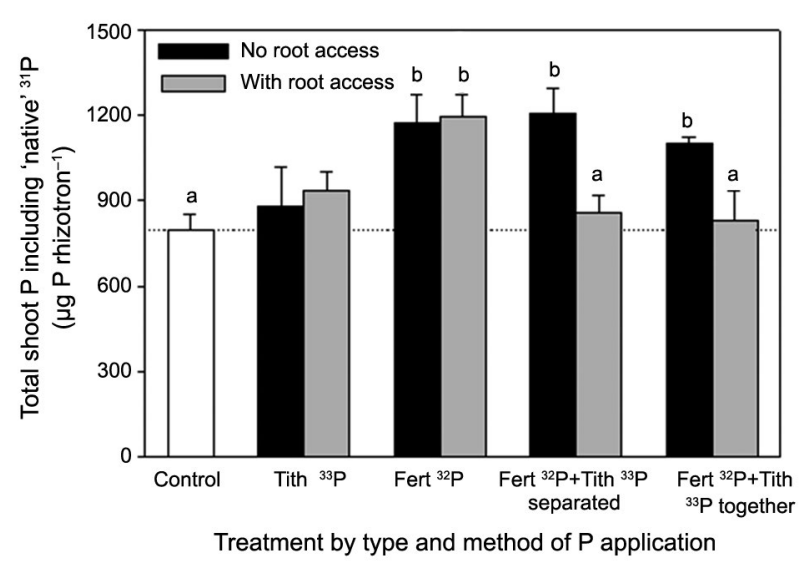

Figure 5 - Total $P$ accumulated in wheat tissue under organic and mineral $P$ sources, with significant differences from the control indicated by letters $(p<0.05)$. Bars are for the standard error of the mean for each treatment $(n=4)$.

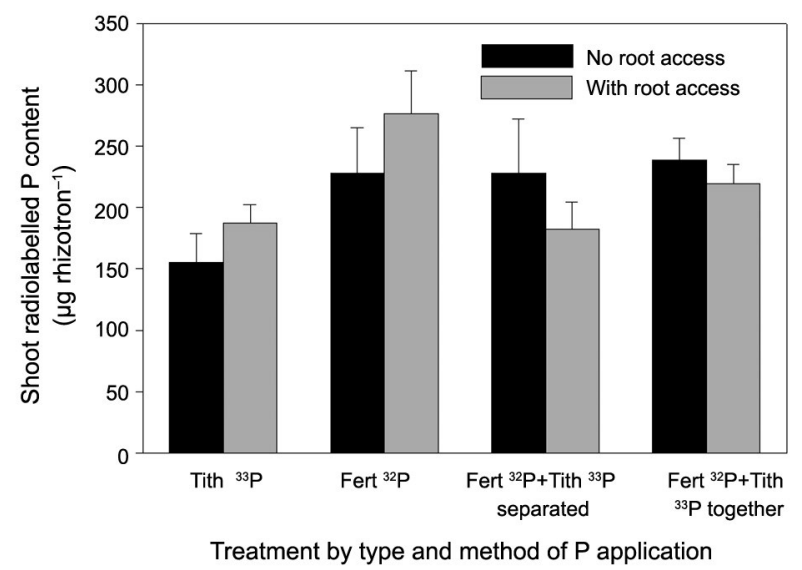

Figure 6 - Radiolabelled shoot $P$ per mesocosm under organic and mineral $P$ sources, with significant differences between treatments indicated by letters $(p<0.05)$. Bars are for the standard error of the mean for each treatment $(n=4)$.

belled $\mathrm{P}$ (Figure 5). Uptake of native $\mathrm{P}$ in the ${ }^{32} \mathrm{Pi}$ treatments and the combined treatments where only mycorrhizas could access the $\mathrm{P}$ hotspot (no root access) were superior to the control. While increased radiolabelled $\mathrm{P}$ uptake was associated with increased native $\mathrm{P}$ uptake (Figure 6), this pattern is not reflected in the DW data. In particular, the increased DW in the 'Tithonia and Pi together' treatment was not related to increased shoot $\mathrm{P}$ concentration.

For a better understanding of the effect of each $\mathrm{P}$ source (i.e. Po or $\mathrm{Pi}$ ) when they were combined in wheat supply, we separated their relative contribution based on isotopic abundance (Figure 7). As no interaction between root exclusion and $\mathrm{P}$ source was detected by ANOVA, the 'with roots' and 'without roots' data was grouped together. When Tithonia ( $\left.{ }^{33} \mathrm{Po}\right)$ was combined

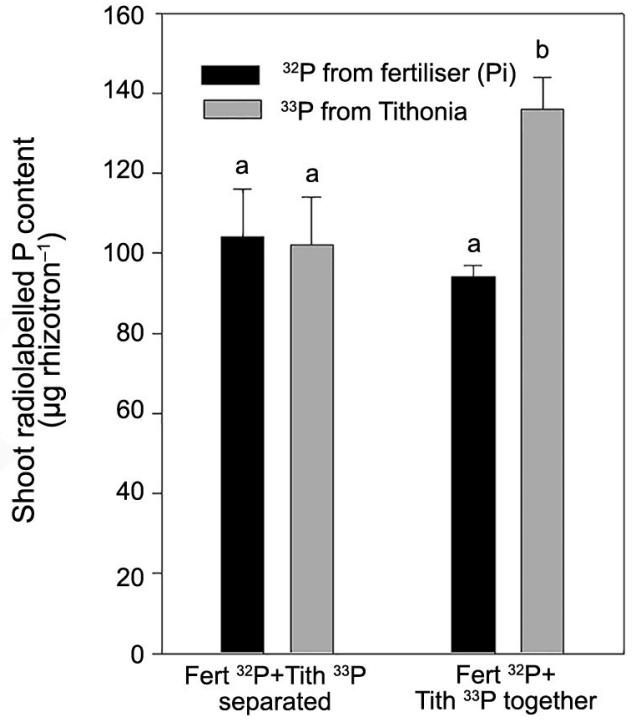

Figure 7 - Radiolabelled shoot $\mathrm{P}$ per mesocosm for ${ }^{33} \mathrm{P}$ Tithonia plus ${ }^{32} \mathrm{Pi}$ treatments, by isotope. Sub-compartments data 'with roots' and 'without roots' have been combined. Significant differences between treatments are indicated by letters $(p<0.05)$. Bars are for the standard error of the mean for each treatment $(n=4)$.

with ${ }^{32} \mathrm{Pi}$, it was the Tithonia ${ }^{33} \mathrm{Po}$ that became more available to wheat plants, but when the two P sources were in separate compartment, the uptake of the $\mathrm{P}$ sources was similar.

\section{Discussion}

There was no effect on the amount of $\mathrm{P}$ uptake from the sub-compartment by wheat, or on the associated growth parameters arising from the exclusion of roots from the labelled sub-compartments. The soil in our study was not inoculated with mycorrhizal spores, but based on previous evidence of mycorrhizal infection of Tithonia plants in the same soil under both laboratory and field studies (Phiri et al., 2003) while it was assumed that viable spores were present. No analysis of the roots to verify mycorrhizal infection of wheat roots was conducted in this study; however, identical mesocosms used in other experiments revealed a moderate level of root colonization (i.e. 25-35\% colonization of the root length). We did not attempt to recover extraradical mycorrhizal hyphae from the soil compartment as we could not reliably distinguish between mycorrhizal and non-mycorrhizal fungal hyphae. Therefore, the following discussion is based on the assumption that transfer of $\mathrm{P}$ from the sub-compartments to the roots of wheat was caused by mycorrhizas rather than by a possible combination of mass flow and diffusion. Since the results presented here suggest that mycorrhizas are as effective in $\mathrm{P}$ acquisition as roots, further work would be justified, both to confirm the finding and to determine the relationship of this effect with $\mathrm{P}$ status. 
Wheat was the crop chosen for use in this experiment, as one of the aims had been to determine if Tithonia residues had a stimulatory effect on mycorrhizas. It was thought that a species with a low mycorrhizal dependence could demonstrate any effect more clearly. This is supported by Sharma et al. (2011) whose results demonstrated that wheat response to AM inoculation alone is not expressive without an extra input of $\mathrm{P}$ fertiliser. As the treatments 'without roots' took up $\mathrm{Pi}$ as effectively as Po supplied from Tithonia residues, no extra stimulatory effect of mycorrhizas is suggested by our data.

The significantly lower root:shoot ratio in the two treatments with access to mineral $\mathrm{Pi}(p<0.05)$ is indicative of an absence of $\mathrm{P}$ stress throughout most of the period of plant growth. The other treatments caused allocation of more resources to root growth (Figure 3). There were no differences in root DW growing in the sub-compartments between the treatments with root access, Consequently, it was decided not to present the data here. This indicates that differences in uptake were not associated with colonisation of the P-hotspot and that the presence of organic matter did not influence the pattern of root growth. P uptake from the labelled sources was, therefore, related to demand and availability.

In the 'Tithonia only' treatments, the relatively small proportion of the total root system occupying the sub-compartments suggests that $\mathrm{P}$ was potentially immobilised by the microbial biomass (Figure 4). Observation of growth and Geiger counter readings during plant growth are compatible with an interpretation of the results that exploitation of the Tithonia-only ${ }^{33} \mathrm{P}$ source was slow, but was increasing at the point of harvest.

The addition of mineral nutrients other than $\mathrm{P}$ to the main compartment soil was used to overcome all other mineral constraints on growth, but the greatest plant growth occurred in plants with root access to combined Tithonia-Po and Pi hotspots. This treatment also resulted in the greatest proportion of the root system to grow in the hotspot. The implication is that while each sub-compartment had only half the amount of Tithonia compared to the Tithonia only treatment, early occupation of this soil by roots foraging for the more available Pi subsequently resulted in enhanced nutrition as other nutrients from the Tithonia became mineralised, since the native soil is poor in most of the nutrients essential for the crop. This in turn resulted in faster growth, albeit with a lower shoot $\mathrm{P}$ concentration.

The ${ }^{32} \mathrm{Pi}$ only treatments with root access developed a greater proportion of the root system within the P-enriched sub-compartment relative to other treatments except for the combined $\mathrm{P}$ source treatment with root access. This finding is compatible with the hypothesis of Forde and Lorenzo (2001) who have proposed a system for the regulation of 'trophomorphogenesis' involving inter- or, more probably, extra-cellular nutrient ion sensor proteins in root cell plasma membranes capable of providing signals to initiate localised nutrient acquisition strategies, but with subsidiarity to systemic chemical signals emanating from the shoot.

Comparison of the 'with root access' and 'without root access' treatments suggests that the amount of native $\mathrm{P}$ in the shoots appears to increase as a result of plants having access to a $\mathrm{P}$ hotspot that is not available to roots, but is available to mycorrhiza (Figure 5). This suggests that plant root colonisation by AM fungi is a whole plant function rather than a localized event. To explore this relationship, we plotted 'native $\mathrm{P}^{\prime}$ concentrations in the shoot against the root:shoot ratio for 'with roots' and 'without roots' treatments (Figure 8). Although there is clearly some variability in the effect, the implication is that where plants are benefiting from the mycorrhizal association in one part of the root system, mycorrhizal activity elsewhere in the root system is increased.

When Tithonia $\left({ }^{33} \mathrm{P}\right)$ and ${ }^{32} \mathrm{Pi}$ were mixed, there was an increase in the uptake of Tithonia ${ }^{33} \mathrm{P}$ by the wheat plants of $\sim 32 \%$ compared to their separated supply (135 $\mu \mathrm{g}$ to $102 \mu \mathrm{g}$, respectively). However, when the two P sources were supplied separately, total uptake of the labelled $\mathrm{P}\left({ }^{33} \mathrm{P}+{ }^{32} \mathrm{Pi}\right)$ was lower than when they were mixed and the two sources were accessed equally (Figure 7). Our interpretation of this result is that the ${ }^{32} \mathrm{Pi}$ constituted a more mobile pool to satisfy the $\mathrm{P}$ sorption potential of the soil and meet part of the microbial demand. As Tithonia ${ }^{33} \mathrm{P}$ was either released from cells as vacuolar ${ }^{33} \mathrm{Pi}$ or ${ }^{33} \mathrm{Po}$ as the Tithonia tissues were mineralised, the reduced buffer capacity and lower microbial $\mathrm{P}$ demand allowed this $\mathrm{P}$ source to be more available to the wheat plants.

Under limited addition of $\mathrm{P}$ mineral in this nutrient poor soil, there was an improvement in yield when Tithonia was mixed with mineral fertilisers, as also reported by Nziguheba et al. $(1998,2002)$. This can be explained in terms of an initial stage where much of the added P from both sources is either adsorbed or immobilised by microbes involved in the decomposition of residues (McLaughlin et al., 2011). This is then fol-

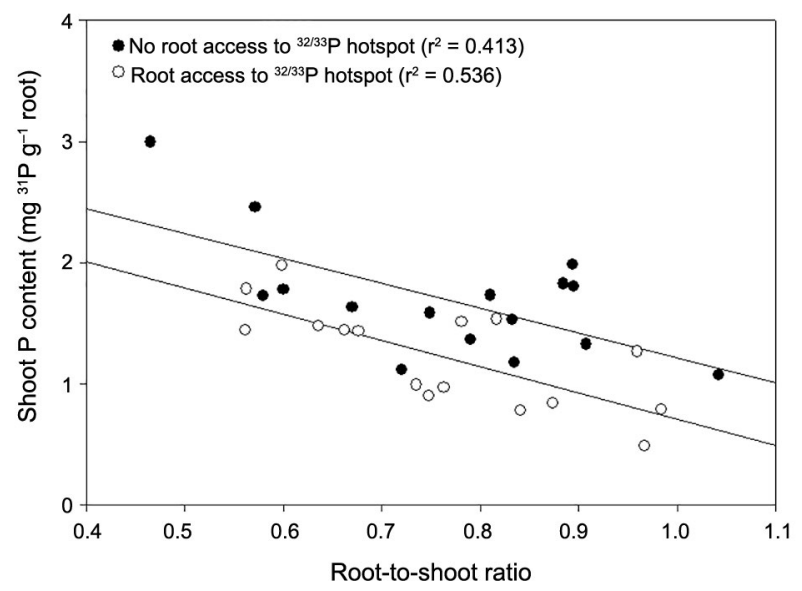

Figure 8 - Plots of native P against root:shoot ratio for 'with roots' and 'without roots' treatments. 
lowed by a gradual mineralisation of Tithonia P. As long as crop plants can meet their initial $\mathrm{P}$ demand, their root systems can colonise the soil effectively to recover $\mathrm{P}$ as it is mineralised. Provided the green manure material decomposes rapidly, as does the Tithonia used here, the mineralisation can be synchronous to plant requirements for better P use efficiency (Faucon et al., 2015).

Tithonia residues usually present high $\mathrm{P}$ concentrations, up to $0.37 \%$, and high DW yield, up to $12.6 \mathrm{Mg}$ $\mathrm{ha}^{-1}$ (Jama et al., 2000). Much of the P in Tithonia tissue is probably in the form of $\mathrm{Pi}$ stored in the vacuole of cells and can be expected to enter the soil very rapidly as cell walls break down (Blair and Boland, 1978). Our results suggest that in addition to the broader beneficial fertilisation effect of Tithonia, the release of $\mathrm{P}$ from this green manure performed a role similar to or even better than ${ }^{32} \mathrm{Pi}$ supplied via mineral fertiliser, reducing the soil buffer capacity and meeting soil microbial $\mathrm{P}$ demand when mineralising this green manure.

This study was not able to show a clear cumulative benefit from the combined mineral $\mathrm{P}$ and Tithonia applications for the recovery of applied $\mathrm{P}$ since their recovery was similar or even lower when Tithonia was applied (Figure 5). It did, however, provide evidence that when applied with mineral $\mathrm{P}$ fertiliser, Tithonia-P is more available than when applied alone (Figures 2, 3 and 7). Further studies over longer time scales would be necessary to establish if other mechanisms can facilitate a greater total recovery from combined $\mathrm{P}$ sources.

It is widely recognised that to overcome the soil fertility and associated poverty problems arising from $\mathrm{P}$ deficiency there must be investment to improve the soil nutrient status in tropical soils (Sanchez et al., 1997; Omotayo and Chukwuka, 2009). This work supports the concomitant application of adequate $\mathrm{P}$ status green manures with an appropriate decomposition characteristic as an effective means of increasing the economic returns from limited $\mathrm{P}$ applications provided the green manure is available at low cost. Although Tithonia was not very effective in supplying $\mathrm{P}$ to wheat, it is clear that its mineralisation can satisfy certain wheat nutrient demands, such as $\mathrm{N}$, by atmospheric fixation, in addition to scavenging and recycling other nutrients from the soil.

\section{Authors' Contributions}

Conceptualization: Scrase, F.M.; Jones, D.L.; Sinclair, F.L.; Farrar, J.F. Data acquisition: Scrase, F.M.; Jones, D.L. Data analysis: Scrase, F.M.; Pavinato, P.S.; Jones, D.L. Design of methodology: Scrase, F.M.; Jones, D.L.; Sinclair, F.L.; Farrar, J.F. Writing and editing: Scrase, F.M.; Pavinato, P.S.; Jones, D.L.

\section{References}

Baker, J.H.; Greweling, T. 1967. Extraction procedure for quantitative determination of six elements in plant tissue. Journal of Agricultural and Food Chemistry 15: 340-344.
Blair, G.J.; Boland, O.W. 1978. The release of phosphorus from plant material added to soil. Australian Journal of Soil Research 16: 101-111.

Brown, L.C. 1971. Determination of phosphorus-32 and -33 in aqueous solution. Analytical Chemistry 43: 1326-1328.

Fairhurst, T.; Lefroy, R.; Mutert, E.; Batjes N.H. 1999. The importance, distribution and causes of phosphorus deficiency as a constraint to crop production in the tropics. Agroforestry Forum 9: 2-8.

Faucon, M.P.; Houben, D.; Reynoird, J.P.; Mercadal-Dulaurent, A.M.; Armand, R.; Lamber, H. 2015. Advances and perspectives to improve the phosphorus availability in cropping systems for agroecological phosphorus management. Advances in Agronomy 134: 51-79.

Forde, B.; Lorenzo, H. 2001. The nutritional control of root development. Plant and Soil 232: 51-68.

Ganunga, R.P.; Yerokun, O.A.; Kumwenda, J.D.T. 2005. Contribution of Tithonia diversifolia to yield and nutrient uptake of maize in Malawian small-scale agriculture. South African Journal of Plant and Soil 22: 240-245.

García-González, I.; Hontoria, C.; Gabriel, J.L.; Alonso-Ayuso, M.; Quemada, M. 2018. Cover crops to mitigate soil degradation and enhance soil functionality in irrigated land. Geoderma 322: 81-88.

Hewitt, E.J. 1966. Sand and Water Culture Methods Used in the Study of Plant Nutrition. Commonwealth Agricultural Bureau, London, UK. (Technical Communication, 22).

International Union of Soil Sciences [IUSS]. 2015. World Reference Base for Soil Resources (WRB): International Soil Classification System for Naming Soils and Creating Legends for Soil Maps. FAO, Rome, Italy. (World Soil Resources Reports, 106)

Iyamuremye, R.; Dick, P.; Baham, B. 1996. Organic amendments and phosphorus dynamics. I. Phosphorus chemistry and sorption. Soil Science 161: 426-435.

Jama, B.; Palm, C.A.; Buresh, R.J.; Niang, A.; Gachengo, C.; Nziguheba, G.; Amadalo, B. 2000. Tithonia diversifolia as a green manure for soil fertility improvement in western Kenya: a review. Agroforestry Systems 49: 201-221.

Kolawole, G.O.; Adigun, C.O.; Akintade, B.O.; Opaleye, O.A.; Lawal, B.A. 2013. Organic residues affect soil P availability, cowpea yield and nutrient uptake on a near neutral P-deficient Alfisol in southwestern Nigeria. International Journal of Applied Agricultural and Apicultural Research 9: 81-90.

Kuivanen, K.S.; Alvarez, S.; Michalscheck, M.; Adjei-Nsiah, S.; Descheemaeker, K.; Mellon-Bedi, S.; Groot, J.C.J. 2016. Characterising the diversity of smallholder farming systems and their constraints and opportunities for innovation: a case study from the northern region, Ghana. Journal of Life Science 78: 153-166.

Marschner, H. 1995. Mineral Nutrition in Plants. 2ed. Academic Press, San Diego, CA, USA.

McLaughlin, M.J.; McBeath, T.M.; Smernik, R.; Stacey, S.P.; Ajiboye, B.; Guppy, C. 2011. The chemical nature of P accumulation in agricultural soils: implications for fertiliser management and design: an Australian perspective. Plant and Soil 349: 69-87.

Murphy, J.; Riley, J.P. 1962. A modified single solution method for the determination of phosphate in natural waters. Analytica Chimica Acta 27: 31-36. 
Nziguheba, G.; Merckx, R.; Palm, C.A.; Mutuo, P. 2002. Combining Tithonia diversifolia and fertilisers for maize production in a phosphorus deficient soil in Kenya. Agroforestry Systems 55: 165-174.

Nziguheba, G.; Palm, C.A.; Buresh, R.J.; Smithson, P.C. 1998. Soil phosphorus fractions and adsorption as affected by organic and inorganic sources. Plant and Soil 198: 159-168.

Olabode, O.S.; Sola, O.; Akanbi, W.B.; Adesina, G.O.; Babajide, P.A. 2007. Evaluation of Tithonia diversifolia (Hemsl.): a gray for soil improvement. World Journal of Agricultural Sciences 3: 503-507.

Omotayo, O.E.; Chukwuka, K.S. 2009. Soil fertility restoration techniques in sub-Saharan Africa using organic resources. African Journal of Agricultural Research 4: 144-150.

Phiri, S.; Rao, I.M.; Barrios, E.; Singh, B.R. 2003. Plant growth, mycorrhizal association, nutrient uptake and phosphorus dynamics in a volcanic-ash soil in Colombia as affected by the establishment of Tithonia diversifolia, Journal of Sustainable Agriculture 21: 41-59.

Rodrigues, M.; Pavinato, P.S.; Withers, P.J.A.; Teles, A.P.B.; Herrera, W.F.B. 2016. Legacy phosphorus and no tillage agriculture in tropical Oxisols of the Brazilian savanna. Science of the Total Environment 542: 1050-1061.

Roy, E.D.; Richrads, P.D.; Martinelli, L.A.; Coletta, L.D.; Lins, S.R.M.; Vazquez, F.F.; Willig, E.; Spera, S.A.; Van Wey, L.K.; Porder, S. 2016. The phosphorus cost of agricultural intensification in the tropics. Nature Plants 2: 16043.
Sakai, R.H.; Ambrosano, E.J.; Negrini, A.C.A.; Trivelin, P.C.O; Schammass, E.A.; Melo, P.C.T. 2011. N transfer from green manures to lettuce in an intercropping cultivation system. Acta Scientiarum. Agronomy 33: 679-686.

Sanchez, P.A.; Shepherd, K.D.; Soule, M.J.; Place, F.M.; Bur sh, R.J.; Izac, A.N.; Mokwunye, A.U.; Kwesiga, F.R.; Ndiritu, C.G., Woomer, P.L. 1997. Soil Fertility Replenishment in Africa: An investment in natural resource capital. p. 1-46. In: Buresh, R.J.; Sanchez, P.A.; Calhoun, F., eds. Replenishing soil fertility in Africa. SSSA-ASA, Madison, WI, USA. (SSSA Special Publication, 51).

Sharma, M.P.; Reddy, U.G.; Adholeya, A. 2011. Response of arbuscular mycorrhizal fungi on wheat (Triticum aestivum L.) grown conventionally and on beds in a sandy loam soil. Indian Journal of Microbiology 51: 384-389.

Souza, E.G.F.; Lima, E.F.; Barros Jr., A.P.; Silveira, L.M.; Bezerra Neto, F.; Cruz, E.A. 2017. Production of lettuce under green manuring with Calotropis procera in two cultivation seasons. Revista Caatinga 30: 391-400.

Withers, P.J.A.; Rodrigues, R.; Soltangheisi, A.; Carvalho, T.S.; Guilherme, L.R.G.; Benites, V.M.; Gatiboni, L.C.; Sousa, D.M.G.; Nunes, R.S.; Rosolem, C.A.; Andreote, F.D.; Oliveira Jr, A.; Coutinho, E.L.M.; Pavinato, P.S. 2018. Transitions to sustainable management of phosphorus in Brazilian agriculture. Scientific Reports 8: 2537. 